IDEA - Studia nad strukturą i rozwojem pojęć filozoficznych

SZKICE FILOZOFICZNE

KATARZYNA POPEK

(Łódź)

\title{
„PROLEGOMENA FILOZOFII PRACY" STANISŁAWA BRZOZOWSKIEGO W KONTEKŚCIE NASZYCH MORDERCZYCH ZMAGAŃ DLA PRZYSZEYCH POKOLEŃ
}

\author{
Bo właśnie dla przyszłej świata szczęśliwości, \\ Domy wam burzą. Po was inne dźwigają ręce \\ Zręby wałów i inne pałace książęce, \\ Nowe ludy wypełnią miasta mury grube, \\ A Północ się wzbogaci poprzez waszą zgubę. \\ Nieszczęścia, co was trapią, ciosy losu złego \\ Są dobrem wedle reguł prawa powszechnego.
}

Wolter, Poemat o zagladzie Lizbony

W cywilizacji, w jakiej przyszło nam żyć i którą uważamy za nowoczesną, stanowczo za szybko zapominamy o zdobyczach dnia wczorajszego. Nasze zużyte zabawki, telefony i inne gadżety codzienności zamienimy na nowsze, bardziej przystosowane do zmieniającej się z zawrotną prędkością rzeczywistości. Tymczasem nie wszystko, co związane z historią, bezpowrotnie przeminęło. Nawet jeśli zarzucimy jakieś wspomnienie niczym stary płaszcz, to zawsze jeszcze może przyjść taka zima, w której ten „łach” będzie naszym jedynym okryciem, naszą osłoną przed wstydem nagości, przed mrozem, przed rażącym światłem słońca (zob. wiersz Andrzeja Bursy, Pedagogika). Fortuna bowiem wciąż wynosi uciśnionych i pogrąża tych, co przez moment stali wysoko. W zasadzie tylko wartości ważniejsze niż życie są w stanie nadać życiu cel, kształt i nasycić je treścią. Jedną z najważniejszych wartości (o ile nie najważniejszą) możliwych do osiągnięcia dzięki trudom życia, a jednocześnie wykraczających daleko poza ciasne ściany celi każdej egzystencji, jest właśnie praca. Jedynie poświęcenie się dla niej - poświęcenie siebie - może dać człowiekowi prawdziwą wolność w każdych warunkach życia. Oto dziś powracają odświeżone idee z przeszłości. Czy Stanisław Brzozowski wygłaszał herezje? I czy właśnie to, co tak pośpiesznie określamy mianem „herezji”, nie powinno 
stanowić dla nas raczej credo, według którego warto byłoby żyć? Podczas gdy praca trawi miękką materię naszego trudu, czy istnieje jakakolwiek inna ścieżka dla przemijania, która pozwoliłaby przetrwać (utrwalić się) temu, co w nas najlepsze, choćby po to, aby kolejne pokolenia mogły się na tym ostać i kontynuować to, czego w jednostkowym życiu może nie uda nam się dokończyć?

Autor Prolegomeny filozofi pracy, Stanisław Brzozowski (ps. Adam Czapiel), urodził się 28 czerwca 1878 r. w Maziarni k. Chełma Lubelskiego. Był wybitnym filozofem, teoretykiem kultury, krytykiem literackim, publicystą i powieściopisarzem. Można powiedzieć metaforycznie, że nie tylko tworzył w swej epoce, ale i ją wyprzedzał, przewidując dalsze koleje. Nie należał jednakże do najszczęśliwszych myślicieli. Najpierw był więziony przez carat za działalność edukacyjną, potem niesłusznie oskarżony o współpracę z carską policją. Zmarł niepocieszony na gruźlicę 30 kwietnia 1911 we Florencji ${ }^{1}$.

Prolegomena filozofii pracy Stanisława Brzozowskiego wskazuje na niezrównaną wartość i społeczny charakter pracy jako potężnej - pod względem żywej materii jaką trawi - aktywności ludzkiej, która zapewnia trwałe warunki niekoniecznie dla własnego życia, ale z pewnością dla życia następnych pokoleń. Odwołując się do słów Woltera, zawartych w motcie tego opracowania, pragnę podkreślić, że w omawianym kontekście praca nie jest bynajmniej wartością w jakikolwiek sposób powiązaną z konsumpcją. Przeciwnie, wartość pracy jest ugruntowana w jej społecznym charakterze, który - posiłkując jakże miękką materię naszych psychicznych i fizycznych uwarunkowań - narzuca sobie twarde restrykcje, bez żadnej obietnicy osobistego zysku czy zbawienia duszy od tego znoju. Moim celem jest ukazanie niezmiennej aktualności filozofii pracy Stanisława Brzozowskiego w rzeczywistości ludzkiej - w rzeczywistości społecznej. Każdy bowiem człowiek ponosi odpowiedzialność nie tylko za siebie, ale również za przyszłość pokoleń. Chociażby nawet nie był nigdy rodzicem, pozostawia po sobie dziedzictwo swojej pracy do dyspozycji innym ludziom. Można tu zaryzykować stwierdzenie, że jednostka, w sensie Brzozowskiego, miękka, krucha i nietrwała, uwiecznia się właśnie dzięki pracy, do której zapał przekazuje dalej, sobie potomnym. Jakże nieatrakcyjnym w tym kontekście wydawać by się mogło burżuazyjne próżniactwo. Pragnę zauważyć, że nawet lenistwo może być naznaczone znamieniem pracy. Wystarczy odwołać się choćby do Prawa do lenistwa Paula Lafargue, by to dostrzec. Stanisław Brzozowski był natomiast myślicielem szczególnym, właśnie dzięki swemu niezmordowaniu w hołdowaniu pracy, w której luki lenistwa to zawsze jednak tylko czarne plamy lub puste pola - zaginione puzzle układanki.

\footnotetext{
1 P. Skrzydlewski, Brzozowski, w: Powszechna Encyklopedia Filozofii Polskiego Towarzystwa Tomasza z Akwinu, t. 1, Lublin 2000, s. 693.
} 
Zdaniem Stanisława Brzozowskiego pojęcie pracy tylko pozornie nie wnosi niczego nowego do filozofii. Myśliciel powołuje się na Goethego, określając pracę mianem „otwartej tajemnicy”. W oparciu o przyjęte wzorce szkicuje również pewną jej definicję, którą można potraktować jako krytyczny punkt wyjścia dla podjętych rozważań: „Pracą nazywamy wysiłek zmieniający coś w sposób celowy w zewnętrznym świecie: z umysłu bierzemy za punkt wyjścia tę formę pozornie najprostszą" 2 .

W Filozofii czynu, chronologicznie poprzedzającej filozofię pracy i będącej zarazem dla niej podłożem, Stanisław Brzozowski stwierdza, że „z każdym dniem uwydatnia się królewskość filozofii nad życiem samem" ${ }^{3}$. Tak oto prezentuje się wzajemna zależność filozofii od kultury ogólnej, gdzie „wszystko (...) jest objęte przez jeden, powszechny związek życia, które samo nie jest niczem innem, jak takiem ciągłem, nieustannie powtarzającem się oddziaływaniem wszystkiego na wszystko, ciągłem, nieprzerwanem pomimo nieustannych przekształceń związkiem; właściwem zaś jest człowiekowi przypisywać tem większe i wyższe znaczenie pierwiastkom tego wzajemnego oddziaływania, im większem uświadomieniem się odznaczają, im bardziej są uduchowione" 4. Jak również zauważa w dalszym wywodzie: „(...) sam ten świat już jest naszą konstrukcyą, wytworem naszej myśli. Czynny nasz udział został wykryty w każdym postrzeganiu jakiegoś przedmiotu" 5 . W spostrzeżeniach, które Brzozowski wysnuwa nie tyko z ludzkich, ale i ze zwierzęcych oczekiwań, że „nasze działania wywołają w świecie tym pewne określone skutki dla nas i skutki te istotnie mają miejsce i wypadają przynajmniej w zasadzie i w ogólnym swym charakterze zgodnie z naszemi oczekiwaniami, czyli w sposób dla nas pożyteczny" ${ }^{6}$, jest owszem miejsce na pewne wyobrażenia o świecie, ,z których [jednak] żadne nie odzwierciedla jego pozapsychicznej przedmiotowej istoty" 7. Chociaż takie celowe i odpowiednio „wyrachowane” działanie, zmierzające do utrzymania się rozwoju w ramach gatunku, może prowadzić do pewnych sprzyjających zmian w świecie, to, jeżeli zmiany te nie będą wynikiem czynu określonego przez pracę, wyróżniającą ze świata natury powszechną zasadę człowieczeństwa - nie będą zakotwiczone w tworzeniu kultury i gleby podatnej dla rozwoju pokoleń na przestrzeni dziejów, które jest możliwe tylko dzięki całkowitemu poświęceniu jednostki. Jak pisze Paweł Pieniążek w książce pt. Brzozowski.

2 S. Brzozowski, Prolegomena filozofii pracy, w: Idee: wstęp do filozofii dojrzałości dziejowej, Lwów 1910, s. 177.

3 S. Brzozowski, Filozofia czynu, w: Idee: wstęp do filozofii dojrzałości dziejowej, wyd. cyt., Lwów 1910, s. 25.

4 Tamże, s. 25.

5 Tamże, s. 44.

6 Tamże, s. 51.

7 Tamże, s. 51-52. 
Wokót kultury: inspiracje nietzscheańskie: „Praca zastępuje czyn. Ta substancja zmienia całą konfigurację myśli Brzozowskiego: praca staje się równoznaczna z kulturotwórczą twórczością, przyroda istnieje niezależnie jako siła obca, destrukcyjna, a kultura pozostaje w ścisłym związku z walką z przyrodą" 8.

Według Pawła Pieniążka takie „pomniejszenie znaczenia jednostki stanowi niewątpliwe odbicie fundamentalnej dwuznaczności, jaka generalnie pojawia się w samym sercu doktryny Brzozowskiego, a mianowicie w pojęciu pracy" ${ }^{9}$. Warto tu zauważyć, że człowiek jest bardzo słaby i kruchy w obliczu świata natury; jest słaby wtedy właśnie, gdy podporządkowuje się tym obiektywnym zasadom. Jeśli natomiast rozwija się w pracy - chroni i pielęgnuje swoją prawdziwie ludzką godność. Brzozowski uważał pracę za solidny fundament istnienia człowieka i podbudowę (zabezpieczenie) dla jego życia. Mówił wręcz o „nadmiernej” trosce o te rozumne wartości narodowe i o pielęgnowaniu, i wzmacnianiu ich w dobrym celu. Warto również zwrócić się tutaj ku temu, co pisze w tej sprawie Andrzej Walicki: „Aby zrozumieć myśl Brzozowskiego, trzeba zdać sobie sprawę, że czym innym była dlań «przyroda» jako przedmiot ludzkiego poznania, a czym innym «przyroda nieuczłowieczona przez żadne pojęcia», przyroda jako bytowo samoistna rzeczywistość pozaludzka” ${ }^{10}$. A dalej czytamy: „W pierwszym sensie przyroda jest naszym własnym tworem: wynikało to z uznania immanencji poznania i aktywnej roli poznającego podmiotu. W drugim natomiast sensie przyroda jest podstawą ludzkiej egzystencji, praca zaś jest tym, co utrzymuje człowieka na tej podstawie, co pozwala mu «ostać się w bycie»" 11 .

Na pozór hermetyczny wykład Brzozowskiego zawarty w Prolegomenie filozofii pracy, po wnikliwszej analizie okazuje się bardzo klarowny. Głęboko ukryte myśli tego filozofa wymagają po prostu, aby je delikatnie odsłonić, a potem śmiało wydobyć. Podobnie jak Jan Paweł II w Encyklice Laborem exercens, Brzozowski uwypukla podmiotowy aspekt pracy, pozwalajaccy zrealizować się człowieczeństwu jednostek, które podejmują jej trud. Myśli te jednak pozostają fundamentalnie odmienne. Podczas gdy Brzozowski niemal personifikuje prace, czyniacc to w duchu przełamanego heroicznym zapałem zwątpienia w idealistyczne wartości, Papież pozostaje wiernym orędownikiem myśli Kościoła. W Pozdrowieniu i Apostolskim Błogostawieństwie otwierających Encyklike, pisze: „Praca (...) oznacza każdą działalność, jaką człowiek spełnia, bez względu na jej charakter i okoliczności, to znaczy każdą działalność człowieka, którą za pracę uznać można i uznać należy pośród całego bogactwa czynności, do jakich jest zdolny i dysponowany poprzez

\footnotetext{
8 P. Pieniążek, Brzozowski. Wokól kultury: inspiracje nietzscheańskie, Warszawa 2006, s. 66.

9 Tamże, s. 70.

10 A. Walicki, Stanisław Brzozowski - drogi myśli, Kraków 2011, s. 74.

11 Tamże, s. 74.
} 
samą swoją naturę, poprzez samo człowieczeństwo. Stworzony bowiem na obraz i podobieństwo Boga Samego (por. $R d z 1,26$ ) wśród widzialnego wszechświata, ustanowiony, aby ziemię czynić sobie poddaną (por. $R d z 1,28$ ), jest człowiek przez to samo od początku powołany do pracy" ${ }^{12}$. Według Laborem exercens człowiek do tego stopnia jest podmiotem, że - jako Boże stworzenie - właśnie dzięki pracy dopełnia Boskiego dzieła. Powołując się na Księge Rodzaju, w jakiej ukazane zostało dzieło stworzenia i stamtąd czerpiąc żywą inspirację dla człowieka, który przez sześć dni w tygodniu ma poświęcać się pracy, Jan Paweł II głęboko wierzył, że istnieje rzeczywistość poza pracą, że siódmego dnia dany jest nam odpoczynek od jej znoju i związanych z nią niesprawiedliwości. W wizji Brzozowskiego natomiast nie odnajdujemy wytchnienia dla jednostki. W ogóle wartość osobnego, ludzkiego bytu pozostaje w jego filozofii zawieszona i możliwa do doprecyzowania tylko dzięki pracy, żmudnej, nieustannej i - bardzo często - dla samej jednostki zupełnie bezcelowej. Tak pojmowana praca zyskuje znaczenie dopiero w kontekście dalekosiężnego spojrzenia na przyszłe pokolenia, które być może (co też wcale nie jest pewne) docenią nasz trud.

Przechodząc już wprost do zawartego w Prolegomenie filozofii pracy wykładu Brzozowskiego, pragnę szczegółowo odtworzyć jego zawartą tam myśl, aby ukazać jej doniosłość i ponadczasowość. Zdaniem tego wiernego orędownika pracy pod warunkiem wyraźnego gestu czy zaklęcia stan naszego ciała przechodzi w stan „świata”. Nie zawsze jest tak, że poprzez określony gest pochodzący od naszego ciała powodujemy zamierzone zmiany w świecie. Zawsze jednak mówimy o pewnej współzależności naszego ciała i świata, i jak pisze Brzozowski: „prawie jednakowo świat otacza ciało, ciało działa na świat, doznaje wrażeń, wrażenia wywołują skojarzenie ruchów mimowolnych i celowych - wszystko jest tu jednakowo jakby dane" ${ }^{13}$. Ze stanami, jakie posiadamy, wiążemy różne marzenia, jednak w myśl Brzozowskiego są one bezradne wobec naszej rzeczywistości w sensie zupełnej przygodności (obojętności) w stosunku do tego, co dane. Tę nieuchwytność, jaka „pośredniczy” pomiędzy stanem danym a odpowiedzią na to, co zadane, trzeba dopiero wytworzyć. Specjalną formę marzeń, a więc marzenia powstające z niemożności stworzenia tego, co stworzyć trzeba ${ }^{14}$, nazwiemy za Brzozowskim marzeniami rozbicia, rozpylenia. „Nieuchwytny gest” $m i$, ten, który dopiero trzeba stworzyć, jest „scharakteryzowany absolutnie negatywnie” ${ }^{15}$. „Mi jest nieznane, zanim dokonane będzie, a gdy jest dokonane, zmienia" - pisze Brzozowski. Podaje

12 Jan Paweł II, Encyklika Laborem exercens, Watykan 1981.

13 S. Brzozowski, Prolegomena filozofii pracy, w:Idee: wstęp do filozofii dojrzatości dziejowej, dz. cyt., Lwów 1910, s. 186.

14 Tamże, s. 187.

15 Tamże, s. 187. 
również następującą definicję: „Praca więc jest twórczością mającą określony cel, mającą wywołać określoną postać naszych uzdolnień czynnych”. Praca to „szczęśliwa forma twórczości" 16. Dopiero forma już przedtem dokonana i wytworzona w sobie, po uprzednim poznaniu zdobyła właśnie piętno pracy. Prawem natury, jak je określa Brzozowski, nazywać będziemy pozostawanie w określonym stosunku rzeczywistości N1 i N2 na skutek rozmaitych oddziaływań pomiędzy nimi czynionych za pośrednictwem „twórczych gestów”, jako już znanych (marzycielstwo) i twórczego gestu $m i$.

W świetle analizy Brzozowskiego: „określone gesty wewnętrzne wywołuja w odpowiedzi określone formy „danej” rzeczywistości” 17. Czy da się to uogólnienie przełożyć na właściwe prawa przyrody? Prostotę działania jednostki przenosimy na złożone działanie całej kulturalnej ludzkości (por. maksyma powszechności u Kanta). „Posłuszna (...) technice przyroda - pisze Brzozowski - stwarza na około szkieletu instrumentów ciało faktów. Fakty przyrodnicze, to ogólnie biorąc, punkt oparcia instrumentu i punkt zastosowania go, oddzielne momenty jego użycia i rezultat" 18 .

Technika naukowa natomiast, wznosząc się nad techniką przemysłową, ma z kolei „poznawać” prawa przyrody; technika danego momentu jest zaś prawdziwym spoiwem tych praw. Fundamentalną podstawą dla nich wszystkich jest cała ludzka działalność. Brzozowski przedstawia związek pracy z prawem ciążenia, sytuując go w naszych praktycznych lub teoretycznych instrumentach (władzach poznawczych i twórczych), które pozwalają nam rozumieć różne formuły.

Według Brzozowskiego bowiem właściwości przedmiotów mówią coś o naszych przeżyciach, prowadzą nas do nich. Zgodnie z tą myślą nie można już mówić o zupełnej prostocie manipulowania przedmiotami tylko w świecie zewnętrznym. Jeżeli zatem przedmiot jest pewną formą naszego życia, to praca z nim/nad nim kształtuje już swoiste zagadnienie, związane z zamierzoną zmianą, prowadzącą nas poza nas. Następuje więc zaklasyfikowanie dokonującego się aktu życia w systemie przeżyć (naszego organizmu). Definiując czyn, Brzozowski pisze, że „,jako ruch jest [on] jakby zarysowaniem się naszej woli nowej na tle dokonanej, usystematyzowanej woli dawniejszej" ${ }^{19}$. Zdaniem autora Idei od przedmiotu będacego „jedną formą życia” do „przedmiotu zmienionego przez pracę" prowadzi zawsze jednoznacznie określona droga. To właśnie siebie określamy przez pracę. Jeśli jej nie wykonujemy, zmiany, jakie się dokonują, nie doprowadzą do II formy życia (przedmiotu zmienionego przez pracę), ale będą przypadkowe w tym sensie, że

\footnotetext{
16 Tamże, s. 187.

17 Tamże, s. 188.

18 Tamże, s. 189.

19 Tamże, s. 178.
} 
nie będą tym, czego chcieliśmy. Wewnętrzny gest to miano oznaczające określoność czynnego napięcia organizmu. Celem czynienia zadość własnej woli, musimy nadać swemu życiu odpowiedni kierunek. Tylko poprzez dokonanie zamierzonego czynu możemy się przekonać o tym, czym jest owa II forma życia. Tajemniczy pierwiastek alfa (i żaden inny) jako kierunek naszego życia jest tym, co trzyma naszą wolę na jego powierzchni. Brzozowski wyraża w tym miejscu przekonanie, że nawet stworzenie określenia własnej istoty jest wynikiem czegoś nieznanego uprzednio jako alfa.

Droga pomiędzy stanami I i II (mieszczącymi się w porządku logicznym) sama jest pozalogiczna. To coś jak właśnie gest czy zaklęcie. Zdaniem Brzozowskiego, tylko dzięki „stworzeniu przez nas” alfa jesteśmy w stanie przejść od stanu I do II, wyjść jakby poza intelekt, by zaraz o tym zapomnieć. „...) do sumy znanych nam, stworzonych przez nas gestów A [musimy] dołączyć nieznany, który trzeba stworzyć, gest alfa, aby z I powstało II" ${ }^{20}$. Po I nie może bezpośrednio nastąpić II! W myśl Brzozowskiego byłoby to logicznym fałszerstwem. Jak też pisze autor Prolegomeny filozofii pracy: „nie ma żadnego a priori znanego nam związku między A i alfa: alfa musi być wynalezione. W stwierdzeniu tym zawarta jest krytyka determinizmu, a także determinizmu metafizycznego, gdzie alfa byłoby określone po zamknięciu się w znanych granicach I i II.

Granicą indeterminizmu jest „konieczność” wcielenia stworzonego przez nas jakiegoś gama w sumę A + alfa. Za sprawą przejścia od I do II czy od II do III nie niszczymy żadnej podstawy, lecz po prostu kształtujemy ją w nowy sposób. Jak pisze Brzozowski: „Świat A + alfa etc. jest światem naszych wewnętrznych przekształceń: pracą w semantycznym nieco znaczeniu będziemy nazywali takie przekształcenie A + alfa etc., na które następuje jako odpowiedź pewna zmiana w świecie I, II etc., to jest w świecie, który jest jakby niezależnie i daje się analizować" ${ }^{21}$. Nasze ciała, zdaniem Brzozowskiego, nie są przedmiotem pracy w ścisłym znaczeniu, gdyż musiałyby być wówczas czymś określonym.

Zgodnie z wykładem Brzozowskiego „(...) nie możemy określać «pracy» przez stanowisko, jakie zajmuje ona w gotowym świecie, gdyż logicznie świat ten nie istnieje, gdy mowa o niej" 22 . Według autora Prolegomeny... po wniknięciu istoty pracy w konkretne życie wszystko staje się jasne i nie potrzeba byłoby już czynić żadnych po temu dowodów. Skłonny do abstrakcji Brzozowski czyni jednak dalszy wywód w poprzednim duchu. Pisze: „Określony, gdy idzie o przejście od jakiegoś I do II, powiedzmy od jakiegoś N1 do N2 - gest wewnętrzny, czynne określenie życia

\footnotetext{
20 Tamże, s. 181.

21 Tamże, s. 182.

22 Tamże, s. 183.
} 
musi (...) być wcielone w poprzednią sumę gestów, w ich ogólny wynikA" 23. Gdy nasze ja znajduje się właśnie ponad A $+n i$, wyrywa się ponad nie, póki nie zdobyło się na $m i$, pozostaje ono w stanie nieokreślonego wytężenia, marzenia.

Według Brzozowskiego przedmioty, w których otoczeniu znajduje się człowiek, nie są przeznaczone do naiwnego ich postrzegania, ale są nam niejako zadane do twórczego przekształcenia przez nasze gesty. „Dany, zastany świat, w obu swych momentach uwarunkowany jest przez pewną fazę tworzenia" ${ }^{24}$. Przydawanie jakiegokolwiek związku pomiędzy N1 i N2 jest zdaniem Brzozowskiego fałszowaniem rzeczywistości. Jest to błąd, który autor omawianego tekstu przypisuje Avenariusowi. Jak podsumowuje Brzozowski: „(..) praca ukazuje się nam jako zmiana, zachodząca w danym gotowym świecie wtedy, gdy straciła ona już znamiona pracy, gdy została dokonana, gdy przestała być bezpośrednio czynnym określeniem własnego naszego życia" ${ }^{25}$. Powołując się na nawiązującego do indywidualnej wartości pracy Bergsona, Brzozowski pisze, że to, co w danej chwili przeminęło, ukazuje się nam jako nasze ciało. Nierozróżnianie czasu pracy i jej połączenia z organizmem nie jest przeszkodą do przejścia od stanu do stanu, kodowanego przez nasz organizm.

Praca, jako gest wewnętrzny, to uzasadnione w swej ostrożności oznaczenie jej wyrazu. „Wszystkie pojęcia, za pomocą których moglibyśmy omawiać pracę - pisze Brzozowski - są w znacznej mierze jej działaniem: analiza doprowadza do tego, że określamy je za pomocą pojęcia pracy; nie możemy więc z natury rzeczy określać pracy za pomocą pojęć, które są jej wynikiem" ${ }^{26}$. W dalszym toku wywodu autor Prolegomeny... usiłuje rozjaśnić pojęcie „gestu wewnętrznego". Wyjaśnia je enigmatycznie, pisząc, że „(...) cecha określonego i przyjętego przez naszą wolę, uwarunkowanego przez nas chcianego użytkowania pewnego momentu naszego życia" 27 jest właśnie pracą. To coś, co bezpowrotnie określa kształt naszego życia. W odróżnieniu od marzenia, praca ma swoje rezultaty, których wynik - choć nieznany - jest jednak trwały. Według Brzozowskiego: „Praca jest wymianą pewnego przeciągu naszego życia na pewne stałe lub względnie stałe, niezmienne lub względnie niezmienne warunki naszego życia" 28. Świat jest współmierny z pracą, „przyjmuje się ją w siebie, zapisuje w sobie i chroni jej wynik" ${ }^{29}$. Poprzez prace wychodzimy poza siebie, osiągając z czasem to, na co możemy liczyć. Zdaniem

\footnotetext{
23 Tamże, s. 183.

24 Tamże, s. 185.

25 Tamże, s. 185.

26 Tamże, s. 190.

27 Tamże, s. 190.

28 Tamże, s. 191.

29 Tamże, s. 191.
} 
Brzozowskiego tylko w oparciu o tak solidny fundament, jak tu omówiony, można skonstatować konsekwentny i pozbawiany sprzeczności światopogląd.

Psychiczna zawartość przemijania może wpływać na świat poprzez pracę, która zapewnia pewne warunki dla naszego dalszego życia. „Zużytkowanie naszego przemijania - zaznacza Brzozowski - ma wyjść poza nas i ustalić coś poza nami" 30. Chociaż świat nie jest bezpośrednio zależny od naszej psychicznej wartości, w jakiś sposób zależy od nas (nie jest niezmienny). Zdaniem autora omawianego tekstu „wszelkie określenie jest złudzeniem” 31 . W jaki sposób nowe warunki życia, będące wynikiem pracy, połączyć z naszą wcześniejszą zawartością psychiczną, jeśli wiemy, że następuje między nimi istotne tajemnicze połączenie? Można za Brzozowskim powiedzieć, że nasze życie „zapłodniło samo źródło czasu tak, że urodzi on pożądany dla nas skutek" ${ }^{32}$; krótko mówiąc - możemy się tego spodziewać. Nie jesteśmy jednak zdolni odtworzyć uczynionej pracy w swoich mięśniach ani w tym, co jest naszym „psychicznym mięśniem”. Za każdym razem praca ma być jak gdyby stworzona, wynaleziona po raz pierwszy ${ }^{33}$. Wytłumaczenie tego, że świat jest dostepny dla pracy za pośrednictwem pojęć o świecie jest pozorne. „(...) współmierność świata i pracy jest istotnie podstawą ostateczną, poza którą nie ma dla nas już właściwie gruntu" ${ }^{34}$. Dostępność świata dla pracy jest zdaniem Brzozowskiego problematyczna i związana ze złudzeniem antropomorficznym. Wyróżnia on dwa możliwe stanowiska w tej kwestii. Pierwsze, uznające, że świat może być - na wzór filozofii Heglowskiej - zamknięty w naszej psychicznej zawartości oraz drugie, niedopuszczające takiej możliwości, przy czym zużywanie się psychicznych wartości może zapewnić dobra jedynie użyteczne, lecz wciąż nie wiadomo, czy to właśnie one są światem, czy też świat w ogóle nie podlega opisowi. Zdaniem Brzozowskiego nie ma większych idealistów niż naturaliści i pozytywiści. W tym kontekście autor zwraca uwagę na tragizm życia człowieka i jego pracy.

W momencie dostrzeżenia trzeciego - nowego stanowiska - psychiczna zawartość „schodzi” na drugi plan. Tu, jak zauważa Brzozowski, zaczyna się nowa logika. „Ginie ta [logika], mocą której usiłował człowiek z procesu porządkowania nabytych wiadomości wytworzyć prawo ich zdobywania: rozpoczyna się żywa, mocą której człowiek żyjąc, życie swe i «poznanie» stwarza" ${ }^{35}$. Problem diametralnego rozbicia starej logiki podejmował F. Schiller. Myśliciel ten zajmował się

\footnotetext{
30 Tamże, s. 193.

31 Tamże, s. 193.

32 Tamże, s. 194.

33 Tamże, s. 194.

34 Tamże, s. 194-195.

35 Tamże, s. 198.
} 
rozczłonowaną w porównaniu z pełną równowagi w Grecji starożytnej popędowością człowieka. Popędy materii i formy, na skutek rodzącej się i doprowadzającej do jakiegoś ukształtowania nowej cywilizacji, nie tylko przestały iść ze sobą w parze, lecz wręcz zaczęły się zwalczać ${ }^{36}$. Zdaniem Brzozowskiego jednak poetycka filozofa Schillera, która jest niewątpliwie wartościowa, nie ma w sobie zmysłu dla historii i zrozumienia zarówno dla ekonomiczno-technicznej, jak i „obyczajowo psychicznej konkretnej budowy społeczeństwa" ${ }^{37}$. Niemniej jednak echa Schillera pobrzmiewają u Brzozowskiego, lecz może bardziej na zasadzie przeciwieństwa. Podczas gdy dla Schillera człowiek całkowicie spełnia się jedynie w grze i zabawie, według Brzozowskiego nasze człowieczeństwo najlepiej realizuje się w pracy ${ }^{38}$.

W myśl autora Idei ,analiza nie jest w stanie wydobyć z założeń nic więcej, jak w nie włożone zostało" 39 . Nie powinniśmy traktować świata jako nam danego i przeznaczonego tylko do odkrywania go. Przecież wciąż go przekształcamy. „(...) Wszystko, co ukazuje nam się jako fakt najbardziej fizyczny, jest zawsze pewną nową właściwością naszego własnego życia, którą zdołaliśmy stworzyć. Nasza ludzka działalność i świat to wciąż dwie odrębne płaszczyzny, jednak „każdy «świat» jest (...) zawsze wynikiem naszej działalności, zapisanej poprzez pośrednictwo tego, co jest istotne poza nami i w naszem psychicznem życiu" 40 . Warto zauważyć, że popierany przez Brzozowskiego w tym względzie Bergson „wyprowadził” świat fizyki z zerwania ciągłości wysiłku ${ }^{41}$.

Autor Idei odwołuje się również do pojęcia ewolucji. Zwraca uwagę, że nie jest ona w żaden sposób uzależniona od naszych treści psychicznych. Brzozowski nie zgadza się jednak z tym, że świat poza nami jest, tak jak w myśli Herberta Spencera, niepoznawalny. Zdecydowanie bliżej mu do Hegla, którego wpływ na przyrodoznawstwo źle oceniali mu współcześni. Brzozowski natomiast bez wątpienia doceniał swoistą procesualność jego filozofii. Jeszcze w odniesieniu do Hegla pisze, że „(...) należy zawsze zdać sobie sprawę, w jaki sposób proces myślowy zlać się może do pełnej tożsamości z procesem bytowym" 42. Zachowując poetykę Brzozowskiego i parafrazując jego myśl, można powiedzieć, że materialiści pragną

36 F. Schiller, Listy o estetycznym wychowaniu czlowieka i inne rozprawy, przeł. I. Krońska, J. Prokopiuk, Warszawa 1972.

37 S. Brzozowski, Prolegomena filozofii pracy, w: Idee: wstęp do filozofii dojrzałości dziejowej, wyd. cyt., Lwów 1910, s. 198.

38 J. Majmurek, Prawo do pracy, w: K. Szroeder-Dowjat (red.), Brzozowski. Przewodnik Krytyki Politycznej, Warszawa 2011, s. 129-130.

39 S. Brzozowski, Prolegomena filozofii pracy, w: Idee: wstęp do filozofii dojrzałości dziejowej, wyd. cyt., Lwów 1910, s. 198.

40 Tamże, s. 199.

41 Tamże, s. 199

42 Tamże, s. 201. 
Hegla przezwyciężyć, zdjąć z chmur jego filozofię i uziemić ją, wplątać w mechanikę świata. Zdaniem autora Idei jednak to, co materialne jest również ideą. Można powiedzieć, że dla marksistów Heglowskie idee nie były zbyt abstrakcyjne, tylko zbyt konkretne. Jak pisze Brzozowski: „Nie ma, nie może być metody, która by wyprowadzała świat, działalność naszą, z jakiegoś systemu zawartości psychicznych, aby sam ten system zawartości trwał t.j. miał znaczenie w ciągu dalszego przemijania" 43 .

Stanowisko Brzozowskiego nie jest idealizmem ani solipsyzmem. Jego zdaniem stanowiska idealistyczne, materialistyczne i naturalistyczne tylko pozornie moga być uważane za jakieś zasadniczo przeciwstawiające się sobie bieguny 44 (wszystkie one pretendują do uznania „psychicznej zawartości” za istotę świata, z tym że idealizm ukazuje, jak ona go stwarza, zaś naturalizm i materializm przyjmuja rezultat i usiłują zapomnieć „proces”) ${ }^{45}$. Przywoływany znów przez Brzozowskiego Bergson dokonuje utożsamienia ewolucjonizmu Spencera z ewolucjonizmem Fichtego, z jednoczesnym podkreśleniem wcześniejszych logicznych potyczek (przed stanięciem wobec świata przyrody) ,ja” Fichteańskiego. Zużywanie swego przemijania przez żywe istoty jest centralnym znamieniem podejścia naturalistycznego.

W kwestii poznania odwołuje się natomiast Brzozowski do ofiary Chrystusa, który na zasadzie zaprzeczenia (logiczny sen), dokonuje realnego unicestwienia „,z krwi i ciała całego życia jednostek i pokoleń” 46. Jak pisze Brzozowski: „U Hegla jest istotnie nieustanna demoniczna walka logiki, intelektualizmu z samoistnością, historyą, z przyjęciem tego, co najogólniej nazwać można Nietzcheańskiem stanowiskiem” 47. Można powiedzieć, że człowiek „oswaja” świat poza sobą jedynie dzięki własnemu ofiarowaniu. Brzozowski wyraża tę oto piękną myśl: „Jeżeli czas przyszły nas nie zawodzi to dla tego, że jest to przeszłość nasza, przeszłość żywych ludzi, co zginęli tak żyjąc, by ten nasz czas był takim, a nie innym. Stąpamy wciąż po tym gruncie" 48 . Być może, tak jak domniemał Brzozowski, na tej ważkiej przesłance można oprzeć nowoczesną treść katolicyzmu? Bez wątpienia na tym gruncie odsłania się samoistne, głębokie i ostateczne znaczenie historii.

Według Brzozowskiego myśl wytwarza wiarę dzięki pierwotnemu wytworzeniu „organów” uzdalniających nas do miłości życia. Postawa wiary jest jego zdaniem bardzo cenna. Autor Prolegomeny... przywołuje różne spojrzenia na naturę

\footnotetext{
43 Tamże, s. 202.

44 Tamże, s. 202.

45 Tamże, s. 202.

46 Tamże, s. 203-204.

47 Tamże, s. 204.

48 Tamże, s. 204.
} 
człowieka, będące wyrazem namysłu takich intelekualistów jak Józef Conrad, Petzoldt czy Bergson. W obiektywie każdego z nich człowiek jawi się z jednej strony jako niezdefiniowany, a z drugiej jako nieustalony. Dopiero to, co tworzymy, staje się bowiem warunkiem naszego przyszłego życia tak, jakby nas tworzyło.

Brzozowski krytycznie odnosi się do tak zwanej filozofii naukowej jako redukującej filozofię do poznania przez człowieka świata poza nim, a więc bagatelizującej wartość realnej ludzkiej działalności. Najniebezpieczniejszy zdaniem autora Idei jest wpływ, jaki nowoczesna „filozofia naukowa” wywiera na pojmowanie historii i życia społecznego, związany z zerwaniem historycznego i narodowego związku, który jest źródłem naturalizmu i pozytywizmu.

Człowiek w pocie czoła tworzy słowa oraz wytwarza wolę. Wszyscy żyjemy w świecie wypracowanym przez naszych przodków. I my dziś pracujemy na ten świat, tworzymy „świat zewnętrzny”. Jak pisze Brzozowski „Nic w nas nie ma, co by nie było historyą, historyą ludzką lub przedczłowieczem biologicznem stwarzaniem się $\mathrm{w}$ męce, nic w nas nie ma, co by nie płynęło z poza nas, co by nie było okupione, stworzone przez wysiłek. (...) [Historia] jest gruntem, który nas dźwiga, unosi ponad otchłanią, z niej jesteśmy i przez nią tylko stykamy się z pozaludzkiem" 49. Kiedyś (niemal tu personifikowana) historia gruntowała się na skutek zużycia żywej zawartości psychicznej. Aktualnie jest ona, według Brzozowskiego, jedynie jej produktem ubocznym. Wówczas gdy zaczyna żyć „myśl zapoznająca swoje pochodzenie" (dokonuje się swoista abstrakcja), związek dziejowy zostaje zerwany. Mowa o filozofiach, które „wyrzucają siebie od razu poza życie" 50. Zdaniem Brzozowskiego nie wystarczy krytykować filozofii, jako niweczącej życie. "Tylko to zostaje pokonane, co możemy zastąpić” - pisze autor Idei ${ }^{51}$. Wskazuje on również na inne, jego zdaniem, groźniejsze od filozofii niebezpieczeństwo, jakim jest kształtujący się po wyzwoleniu od niej filozoficzny eklektyzm. „(...) nie może być mowy o rezygnacji z filozofii, która nie byłaby jednocześnie rezygnacją ze świadomości" 52 - konstatuje we własnym duchu, pisząc o filozofii prawdziwie głębokiej. Grzechem filozofii jest być może niedocenianie jednostkowego życia kosztem waloryzacji zawartości psychicznej, którą konstytuuje cała historyczna diachroniczna zbiorowość.

Bezwzględne potwierdzenie, jako typ życia, ukazane przez przywoływanego w Prolegomenie... Woltera, nie może jeszcze wzbogacić naszych wnętrz treścią przeżyć, ponieważ nie została osiągnięta swoboda od filozofii. Gdy wyrywamy się z istotnego szczerego stosunku do życia, uzależniamy się od „nieznanych nam

\footnotetext{
49 Tamże, s. 207.

50 Tamże. S. 208.

51 Tamże, s. 208.

52 Tamże, s. 209.
} 
przyjmowanych w rachubę sił" 53 . W pracy Brzozowskiego pobrzmiewają odniesienia do Kanta, jednak z odmiennego, historycznego punktu widzenia. Kosztem świata, bytu i duszy „wszystko staje się własnością pewnego konkretnego przemijania, osiągniętą dzięki temu, że czas, przemijanie innych ludzi zostały i zostają w pewien sposób zużytkowane" 54 . W ten właśnie sposób historia staje się „siłami życia". Nasze życie porównujemy wciąż z żywym światem. "Czujące serce” ludzkie wzniesione ponad codzienną krzątaninę i udręczenie pracą - zaczyna pojmować nowy bezwzględny ideał, jakim jest buddyzm. Sentymentalizm jednak jest zdaniem Brzozowskiego pewnym zwyrodnieniem duszy. Wyzwolić się spod jego władzy można, jak pisze: „tylko tworząc biologicznie zwycięską przyszłość człowieka i zachowując to, co on zdobył" 55 .

Brzozowskiego dręczą wątpliwości o status idei kiedyś ludzkich, a dziś bezpowrotnie przemijających w tym, co pozaludzkie. Czyżby wszystko było już tylko pochodne i zewnętrzne (jak u Simmla czy Poincarego), a już nie pierwotne i źródłowe? To - jak pisze - „ostry pierwiastek Nietzcheańskiego powietrza, pozbawiający myśl każdą i każde uczucie wszelkiej miary, nadający im charakter niewierzącego w siebie początku" 56. Typowym złudzeniem jest to, że można myśleć o życiu, nie nadając mu kształtu. Próbując nazwać to, co nieokreślone, Brzozowski pisze, że „pozornie tylko mówimy wewnętrznie i zewnętrznie, właściwy świat jest niemy". Podświadome dojrzewanie naukowych hipotez i rozwiązań, według Poincarego, jest czymś takim właśnie. Na uzasadnienie tezy, że: „nie poznajemy niczego prócz naszego życia, a życie nie może być poznane" ${ }^{57}$, Brzozowski pisze, iż to co tworzymy, jest w zasadzie tylko środkiem do tego, żebyśmy żyli. Czy można więc powiedzieć, że życie jest celem pracy? Sam Brzozowski zdaje się taką tezę ryzykować. Wszystko zaś, co po nas zostaje (co wytwarzamy), niby najpierw służy nam za oparcie, ale później okazuje się produktem ubocznym pracy - zaczyna żyć własnym życiem. Pozór jako charakter życia na tle nieskończonej skuteczności to bardzo celne tutaj odwołanie do Heglowskiej prawdy, która połyskuje właśnie na zasadzie kontrastu z pozorem.

W kwestii tego, co na swój sposób kontrastuje z pracą i co, być może, nadaje jej właśnie prawdziwą wartość, pokuszę się tu może o pewną dygresję i przywołam głos Paula Lafargue, który w Prawie do lenistwa wyraża następujące przesłanie: „Filantropi nazywają dobroczyńcami ludzkości tych, którzy sami nic nie robiąc, dla wzbogacenia się dają pracę biednym. Stokroć lepiej by było szerzyć zarazę,

53 Tamże, s. 210

54 Tamże, s. 210.

55 Tamże, s. 212.

56 Tamże, s. 212.

57 Tamże, s. 214. 
zatruwać źródła, niż zakładać kapitalistyczne fabryki wśród rolniczej ludności. Wprowadzenie pracy fabrycznej kładzie kres radości, zdrowiu, wolności, wszystkiemu, co czyni życie pięknym i godnym przeżycia" 58 . Nie był to bynajmniej pierwszy filozof, który pochwalał „zażywanie wczasu”. Już w starożytności pisał o tym (choć w innym duchu) Arystoteles: „Czynić (...) wysiłki i pracować dla rozrywki wydaje się czymś niemądrym i zgoła dziecinnym; słuszną natomiast rzeczą zdaje się być - zdaniem Anacharsisa - zabawa, której celem jest poważny wysiłek. Bo zabawa jest pewną formą wypoczynku, a człowiek potrzebuje wypoczynku, ponieważ nie może pracować bez przerwy. Nie jest więc wypoczynek celem, lecz środkiem do celu, którym jest działanie" 59 . Praca, pozostająca natomiast celem odpoczynku, także powinna odnajdywać umiłowany przez Filozofa złoty środek. Arystoteles, który cel życia utożsamiał z celem wychowania, miał bez wątpienia wiele racji. Sprowadzając jego myśl do współczesnej wizji ludzkiej egzystencji, również trudno jest zaprotestować, że sama w sobie praca nieskończenie wyniszcza zaangażowane w nią jednostki. Wyważony odpoczynek natomiast (choć może nie lenistwo) pozwala człowiekowi zakumulować siły do nowego wytężonego działania dla dobra ludzkości. Sam Brzozowski pozostawał natomiast wierny swojej wizji pracy aż do całkowitego wyniszczenia, aż do osobistego zwycięstwa nad światem przemijania.

Rzeczywistość według autora Idei wciąż się staje, nie jest skończona. Ludzki świat ze względu na kształt naszego życia i nasze władze psychiczne - chociaż nas przeraża - jest jedyną podstawą naszego życia i naszych słów. Czy czas poza nami zależy od czasu w nas? Byłoby to ryzykowne stwierdzenie. Czy metafizyczne czyny wynikają tylko z fizjologii mózgu? Chłodny, obojętny czas stwarzania się jest fikcją. W rzeczywistości tworzymy siebie w żarze, wykonujemy pracę, coś, co pozostawimy po sobie. W ten sposób Ludzkość przeżywa wszystko przez jednostki. Powołując się na Nietzchego, Brzozowski pisze: „Cała powszechna nasza rzeczywistość jest naszym nieustannym dziełem" 60. Autor Prologomeny... nawiązuje również do myśli G. K. Chestertona, który pisze o istocie „sąsiedztwa”. W odróżnieniu od przyjaciół „sąsiad” jest osobą, o której towarzystwie decyduje sam los. Od naszego sassiedztwa uciekamy w świat, by nagle odnaleźć samych siebie $\mathrm{w}$ tej dziwnej pogoni. Właśnie ta pogoń, to życie, te nasze wewnętrzne drgania są najtrwalsze ze wszystkiego, co nas otacza, z wszelkich automatyzmów, wykraczają pod tym względem nawet poza kosmiczną harmonię. Ta nasza codzienna krzątanina jest bowiem potężną machiną napędzającą nasze życie.

58 Paul Lafargue, Prawo do lenistwa, przeł. I. Bibrowska, Warszawa 2006, s. 7.

59 Arystoteles, Etyka Nikomachejska, przeł. D. Gromska, w: Dziela wszystkie, t. 5, Warszawa 2000, s. 289.

60 S. Brzozowski, Prolegomena filozofii pracy, w: Idee: wstęp do filozofii dojrzalości dziejowej, wyd. cyt., Lwów 1910, s. 217. 
„Harmonia sfer trzyma się na krwawym słupie ludzkiego wysiłku” 61 - pisze Brzozowski. Wierzymy, że kolejne pokolenia przejmą nasz trud, a nie ma w umyśle pierwiastka, który nie byłby częścią jakiejś pracy. Chodzi jednak o to, żeby praca została zużytkowana w określony sposób. Utrzymująca samą siebie rzeczywistość jest konsekwencją motywu czyjegoś psychicznego czasu. Postulat Brzozowskiego, że „świat musi być i moim światem” 62 , ma wielkie znaczenie dla naszej własnej prywatnej niemal pracy we własnym ,zakątku rzeczywistości”. To wszystko jest dla nas ważne ze względu na antycypację naszej przyszłej aktywności. „Nie można orzec nigdy, co jest lub nie jest motywem niezbędnej pracy" 63 .

Sprawiedliwość, słuszność itd. to dla Brzozowskiego puste retoryczne terminy. Dopiero ostateczna forma rozważana w zagadnieniu metafizycznym jest tak istotna dla człowieka. Świat w jego określonej formie jest zależny od ludzkiej aktywności. Tu pobrzmiewa apel Kantowski, aby pomimo kosztów, jakie trzeba ponieść, pragnąć istnienia człowieka właśnie ze względu na świat (nawet jeśli dla Kanta to tylko postulat), w którym żyjemy i ze względu na naszą godność. Czy nasze istnienie jest „upokarzającym musem” czy raczej czymś swobodnym? - zapytuje Brzozowski. W enigmatycznej, aczkolwiek dosadnej odpowiedzi autor Prolegomeny moc i piękno moralne przypisuje klasowemu ruchowi proletariackiemu.

Zdaniem Brzozowskiego „wyodrębnienie klasowe proletariatu jest jedyną droga prowadzącą do ugruntowania moralnej atmosfery w ludzkości, do odnalezienia sensu słowa człowiek" 64. Człowiek dostrzega sens w swojej pracy i w swoim cierpieniu, żyje ze względu na rzeczywistość, której pragnie jako swojego sensu i celu świata. Praca musi być swobodna, aby była autentyczna, żeby mogła regulować ludzką tożsamość. W przeciwnym razie „człowiek będzie nie istotą metafizyczną, lecz czymś utrzymywanym przez strach i użycie w nałogu trwania" 65. Brzozowski wierzy w znaczenie walki robotniczej. Jeżeli właśnie ona decyduje o socjalizmie, to autor Prolegomeny filozofii pracy sam siebie określa mianem socjalisty.

Istnienie człowieka uznane za bezwzględne jest niezależne od dóbr życia. „Człowiek istnieje, bo pracuje, utrwala pracą swoje istnienie: kto nie pracuje, nie ma głosu" 66 - pisze Brzozowski. Ogromne znaczenie dla pracy ma uczciwa myśl. Niestety dla mas ludzi sprawiedliwość to po prostu ustrój. Proletariat, zdaniem Brzozowskiego, miał zwyciężyć właśnie dzięki intensywnej, przekraczającej standardy, pracy. Ruch klasowy proletariatu, skonstatowawszy na poziomie emocji

61 Tamże, s. 219.

62 Tamże, s. 220.

63 Tamże, s. 220.

64 Tamże, s. 222.

65 Tamże, s. 223.

66 Tamże, s. 224. 
cały ciężar życia, miał stać się ,,jedynym, wielkim, zachowawczym ruchem ludzkości" ${ }^{67}$. Dla jego powodzenia potrzeba było zasobów i dopingu pochodzących od polskiego narodu, który jednak przez „upośledzone społeczeństwo” 68 sam blokował klasę pracującą. „Człowiek bez narodu jest - według Brzozowskiego - duszą bez treści, obojętną, niebezpieczną i szkodliwą" ${ }^{69}$. Należy mieć na uwadze historię swojego narodu, swojej własnej osobistej pracy i morderczej pracy pokoleń. Historia bowiem wszystko wyklaruje, z ziemią zrówna klasowe szlachectwo, ocali jednak to, co we wszystkim było rozumne.

Stanisław Brzozowski bez wątpienia oddał pracy należny hołd. Mówiąc na przykład, że niemożliwe jest przejście od jednego do drugiego zaplanowanego stanu bez odpowiedniego, choć w zasadzie nieuchwytnego poza odczuwalnym wysiłkiem, przepracowania tej unikalnej drogi, wyraża moim zdaniem sens i charakter ludzkiego rozwoju w ogóle - dokonującego się właśnie poprzez pracę. Życie pokoleń jest możliwe dzięki pracy, która zapewnia trwałe warunki przyszłego bytowania i wyzwala zarazem niezłomny temperament jednostkowego, morderczego nawet budowania. Postulatem Brzozowskiego jest wspólne budowanie w ramach niekwestionowanego jego zdaniem mentalnego zwycięstwa ruchu robotniczego, któremu sam bardzo kibicował, dostrzegając jak wiele jeszcze potrzeba rozeznania w polskim społeczeństwie, aby ten „wyzwoleńczy zryw” mógł nie tyle dojść do skutku, co osiągnaćc bezapelacyjny tryumf. Zawołaniem „kto nie pracuje, nie ma głosu” Brzozowski wyraźnie ukazuje, na czym polegać by miały waga i odpowiedzialność życia narodu w „nieupośledzonym społeczeństwie”.

Jak zauważa Andrzej Walicki: „O «obrońcach ludu» pisze się w cudzysłowie, z ironią, domaganie się środków na elementarne przeżycie jest «roszczeniowością». Słowem, zmasowany atak ludzi zamożnych i wykształconych na ciemną masę, która bezczelnie uważa, że i jej coś się należy" 70. Czy zatem można powiedzieć, że cała Prolegomena filozofii pracy kryje w sobie pierwiastek przemocy? Tak na pewno nie jest. Przecież Stanisław Brzozowski z ogromnym entuzjazmem i zarazem bólem w sercu poświęcił swoją myśl ludziom, których uważał za pokrewne mu dusze. Był wiernym orędownikiem prostych ludzi, a przy tym orędownikiem pracy.

Nieustannie zważając na zawarte w motcie słowa Woltera, pragnę zacytować fragment innego jego dzieła, a mianowicie krótką rozmowę Kandyda ze starym ogrodnikiem:

"- Musisz posiadać - rzekł Kandyd do Turka - rozległe i wspaniałe majętności?

\footnotetext{
67 Tamże, s. 224.

68 Tamże, s. 225.
}

69 Tamże, s. 225.

70 A. Walicki, Kratki z dziennika 1998-2006, w: O inteligencji, liberalizmach i o Rosji, Kraków 2007, s. 379-380. 
- Tylko ten kawałek ogrodu; uprawiam go z dziećmi; praca oddala od nas trzy wielkie niedole: nudę, występek i ubóstwo" 71 .

Myślę, że fragment ten znakomicie uwyraźnia bezpośrednio wartość pracy (dla) człowieka.

Podsumowując, chcę zadać pytanie: czyż nie warto dać się ponieść namiętnej pracy w trosce o własną moralność i o własny godny byt, już dziś hojnie obdarowując przyszłe pokolenia, które ze swej strony same będą musiały pojąć, jak ogromną wartość stanowi ta substancja? Bez pracy nie ma podmiotowego życia; wszelka jego możliwość musiałaby pozostać utajona w potencjalności naszego człowieczeństwa. Oddana pracy heroiczna walka dla przyszłych pokoleń ma ogromny sens nie tylko w niezwykłej konfiguracji myśli Brzozowskiego, ale w każdej filozofii, ceniącej podmiotowość. Chociaż zaprezentowana tu myśl sprawia wrażenie mrocznej, bez wątpienia wpisuje się w pojemne naczynie mistycyzmu. Czy jednak można mówić o mistycyzmie, w którym Bóg zostaje „zastąpiony” jakąś inną naczelną dla duszy wartością, która przecież nie jest żadną mamoną, ale właśnie substancją mającą uszlachetnić życie? Należy jednak pamiętać, że praca nie tylko uszlachetnia, ale i uzależnia. Czy więc za przekrwionymi oczami człowieka, który nie widzi już siebie, ale tylko owe przyszłe pokolenia, może jeszcze kryć się wyobrażenie o własnym szczęściu i samorealizacji w konstytuowanym przez swoją nieugiętą pracę człowieczeństwie, jakie dzięki niemu stanie się być może jeszcze powszechniejszą zasadą?

\title{
"PROLEGOMENA FILOZOFII PRACY" BY STANISEAW BRZOZOWSKI IN THE CONTEXT OF OUR MURDEROUS STRUGGLE FOR FUTURE GENERATIONS
}

\begin{abstract}
Summary
Without doubt "Prolegomena filozofii pracy" by Stanislaw Brzozowski sets in a historical perspective the trail which we can go through not only thanks to our serious effort, but also to the intangible internal gesture. According to this philosopher, the work irreversibly determines the shape of our lives; it creates a world of culture. What is more, life is its purpose in the sense that it makes permanent transformations in the world that protects human life - not necessarily our own! According to this new logic, man creates his life and the cognition of himself. Reconstruction of murderous mental rite of work is impossible, because living matter wears just down through the work. However, according to Brzozowski, we cannot know anything except our own life. We constantly think about it, we give it some shape. The author passionately draws from Hegel's philosophy of process, but he arrives at his own
\end{abstract}

71 Wolter, Kandyd, w: Powiastki filozoficzne, przeł. Tadeusz Boy-Żeleński, Kraków 2003, 342. 
implications. Brzozowski has made a specific identification of consciousness with a deep philosophy. In his opinion, our fear of the future would not be justified if we could rely on the work of our ancestors. However, work remains our constant challenge. In general, a person is very weak and fragile in the face of the world of nature. We are weak when we are subordinated to the objective rules. If a human develops in the work - he and she protects and cares for their truly human dignity. Brzozowski was a rebelious thinker. He believed in the cause of the working class even more than their own strength. I would like to dedicate my article to Stanislaw Brzozowski to demonstrate what a piercing philosopher and a theorist of social thought he was.

Key words: class struggle, work, consciousness of life, philosophy of process

Słowa kluczowe: walka klasowa, praca, świadomość życia, filozofia procesu

\section{Bibliografia}

Arystoteles, Etyka Nikomachejska, przeł. D. Gromska, w: Dzieta wszystkie, t. 5, Warszawa 2000.

Brzozowski S., Filozofia czynu, w: Stanistaw Brzozowski, Idee: wstęp do filozofii dojrzaŁości dziejowej, Lwów 1910.

Brzozowski S., Prolegomena filozofii pracy, w: Stanisław Brzozowski, Idee: wstęp do filozofii dojrzałości dziejowej, Lwów 1910.

Jan Paweł II, Encyklika Laborem Exercens, Watykan 1981.

Lafargue P., Prawo do lenistwa, przeł. I. Bibrowska, Warszawa 2006.

Pieniążek, P.,Brzozowski. Wokół kultury: inspiracje nietzscheańskie, Warszawa 2004.

Majmurek J., Prawo do pracy, w: K. Szroeder-Dowjat (red.), Brzozowski. Przewodnik Krytyki Politycznej, Warszawa 2011.

Schiller F., Listy o estetycznym wychowaniu człowieka i inne rozprawy, przeł. I. Krońska, J. Prokopiuk, Warszawa 1972.

Skrzydlewski P., Brzozowski, w: Powszechna Encyklopedia Filozofii Polskiego Towarzystwa Tomasza z Akwinu, t. 1, Lublin 2000.

Walicki A., Stanisław Brzozowski - drogi myśli, Kraków 2011.

Walicki A., Kratki z dziennika 1998-2006, w: O inteligencji, liberalizmach $i$ o Rosji, Kraków 2007.

Wolter, Poemat o zagladzie Lizbony, przeł. Aleksander Wołowski, w: „Literatura na świecie", 4, 1979.

Wolter, Kandyd, przeł. Tadeusz Boy-Żeleński, w: Powiastki filozoficzne, Kraków 2003.

mgr Katarzyna Popek - doktorantka IHSD Uniwersytetu Łódzkiego, Instytut Filozofii, Katedra Historii Filozofii 